\title{
TANÁRKÉPZŐK AKADÉMIÁJA IV.
}

\section{PFister Éva}

a Budapesti Corvinus Egyetem Magatartástudományi és Kommunikációelméleti Intézetének adjunktusa, a TKSZ titkára

eva.pfister@uni-corvinus.hu

2009. január 30-31-én került sor a Tanárképzők Szövetsége szervezésében a Tanárképzők Akadémiájának negyedik rendezvényére Győrött, a Hotel Famulus tanszállodában.

Az összejövetel célja a tanári mesterszak 5. félévi gyakorlatának tartalmi és szervezeti megoldási lehetőségeiről való közös gondolkodás és egy javaslat megfogalmazása. Az összejövetelre több mint 130 kolléga érkezett az ország minden részéből, szinte minden magyarországi tanárképző intézmény képviseltette magát.

2009. január 30-án, péntek délelőtt az ún. „Előakadémia” keretében a részvevők a következő előadásokat hallgathatták meg:

- N. Kollár Katalin: A tanári MA 5. féléve az ELTE modellben;

- Poór Zoltán: A mentorképzés tartalma és módszertana;

- Magyar István: Elektronikus portfólió az Eszterházy Károly Főiskolán;

- Enyedi Ágnes: A külső iskolai gyakorlat a nyelvtanárképzésben.

Az előadásokat követően lehetőség nyílt kérdések, vélemények megfogalmazására. Ebéd után került sor a Tanárképzők Akadémiájának „hivatalos” megnyitójára. Köszöntőt mondott Falus Iván, a Tanárképzők Szövetségének és Cseh Sándor az Óvó- és Tanítóképzők Egyesületének elnöke. A délután első felében a következő elöadások hangzottak el:

- Manherz Károly, OKM szakállamtitkár: A tanárképzés előtt álló feladatok az oktatáspolitika nézőpontjából;

- Stéger Csilla, OKM szakreferens: A bevezető szakaszra vonatkozó európai elképzelések;

- Iker János, OKM szakértői bizottság: A szakértői bizottság munkájának eredményei.

A programon részt vett még Rádli Katalin OKM föosztályvezetö-helyettes asszony is. A délután hátra lévő részében, illetve az éjszakába nyúlóan az akadémia résztvevői különböző összetételü munkacsoportokban dolgozták ki elképzeléseiket az 5. féléves gyakorlatról, saját szerepükről a gyakorlat előkészítésében és megvalósításában.

2009. január 31-én, szombaton reggel Bazsa György (a MAB elnöke) elöadásával folytatódott a program „A tanári mesterszak indításának tapasztalatai - az 
akkreditáció oldaláról" címmel ${ }^{1}$. A kérdéseket, észrevételeket követően került sor az akadémia ajánlásainak, állásfoglalásának plenáris ülésen történő megfogalmazására. Ehhez azonban az idő kevésnek bizonyult, így a végleges szöveg kialakítására Falus Iván, a TKSZ elnöke vállalkozott, amelynek első változata már fel is került a TKSZ honlapjára. Az érdeklődők az ajánlást a következő címen érhetik el: http:// www.pedagogia-online.hu/tksz/_dok/ajanlas_gyor.pdf

Az összejövetelt a Tanárképzők Szövetségének küldöttgyülése zárta. Itt került sor Falus Iván elnök beszámolójára, amelyben összegezte a TKSZ elmúlt évi tevékenységének eredményeit, valamint a jövöre vonatkozó elképzeléseket. Ezt követték a TKSZ szakosztályvezetőinek beszámolói (Bánhidyné Szlovák Éva - Szakképzési Szakosztály; Elek Elemérné - Oktatásinformatikai Szakosztály; Katona András Szakmódszertani Szakosztály, Szabó Antal - Pedagógiai Szakosztály). A jövőben kerül sor a Pszichológiai-, a Személyiség- és képességfejlesztő, valamint az Egészségpedagógiai Szakosztály tisztújítására. Javaslat hangzott el egy új „Mentorpedagógiai Szakosztály" létesítésére Poór Zoltán és Kotschy Beáta közremüködésével.

A konferencia előadásainak anyagai, valamint több, a tanárképzést érintő anyag megtalálható a Tanárképzők Szövetsége honlapján, amely a következő helyen érhetö el: http://www.pedagogia-online.hu/tksz/

\footnotetext{
${ }^{1}$ Jelen számban az Eszmecsere rovatban olvasható Bazsa György előadásának szerkesztett változata.
} 